\title{
MÓNIKA SZEGEDI
}

\section{An Initiation Rite in Tibetan Historiography}

Historiography in Tibet shows many features of syncretism, similarly to Tibetan Buddhism in general. Beyond containing records of actual events, Tibetan historiography is full of etiological myths modified according to current ideological needs, yet preserving many ancient motifs. These express not only the origins of the Tibetan people but also the wider context of the movements and interactions of the different peoples of India, Tibet and China. ${ }^{1}$

In this paper I shall investigate a quasi-historical event in the biographies of the second 'Dharma King' of the Tibetan Empire, Khri-srong Lde-btsan (Trisong Detsen ${ }^{2}$ ). As the newborn heir to the throne, he was stolen from his mother by a rival queen; however, at a ceremonial event the still infant prince indicated his true descent by sitting on the lap of his maternal uncle. As Ruzsa (2016) noticed, the complex motif of the new ruler choosing his family by sitting on the lap of a male representative can be found in the Indian legend of Sunahiśepa, embedded into a much richer structure. Following his reconstruction, by analysing further parallelisms in a wider corpus, it appears that the seemingly innocent story of a baby prince is, in fact, a remnant of an archaic rite. I argue that originally this was a rite of passage, related to a special variant of puberty initiation: the consecration of the heir apparent. Furthermore, its relationship to the Indian legend of Sunahśepa connects it indirectly with the stories of Isaac and even Snow White and also with several rites of passage in ancient Greece. ${ }^{3}$ I will also

${ }^{1}$ Szegedi 2013a, Szegedi 2013b.

2 All Tibetan text, names and titles are in Wylie's transcription. The approximate pronunciation is given in brackets after the first occurrence of those names, which are used in that form in a translation quoted here.

${ }^{3}$ I am deeply thankful to Professor Ferenc Ruzsa for his valuable suggestions and very inspiring comments. 
suggest that some versions of the legend point to a probably even more obsolete cycle of maternity rites with parallels in Solomon's judgment and the Chinese Chalk Circle.

\section{Khri-srong Lde-btsan chooses his family}

Khri-srong Lde-btsan ${ }^{4}$ was the second "Dharma king" (chos-rgyal) of Tibet, called so on account of his strong and effective support of Buddhism. He ruled between 755 and 797, more than a century after the founder of the Tibetan empire, the first Dharma king Srong-btsan Sgam-po. His empire was huge, and he was militarily very active; in the west, fighting the Abbasid Caliph at the Oxus (Amu Darya), while on the East even occupying the Chinese capital Chang'an in 763, although he was unable to hold it for long. ${ }^{5}$

Interestingly, according to Tibetan Buddhist historiography, Khri-srong Lde-btsan was himself half Chinese: he was born to the third wife of his father Khri-lde Gtsug-btsan (704-755), nicknamed Mes Ag-tshoms, "Bearded Grandfather". Mes Ag-tshoms' first wife was from the Nanzhao kingdom (Tib. Ljang or Ljongs; south of the Tibetan-Chinese border), the second one was from the important Tibetan Sna-nam (Nanam) clan, and the third wife was Kim-shing kong-jo (Kyimshing Kongjo, Jincheng Gongzhu 金城公主), the (adopted) daughter of the Chinese emperor.

The quite unusual story of the birth of Khri-srong Lde-btsan is described in several ancient chronicles. Three works, representatives of three eras in the history of Tibet, are presented here. The well-known and authoritative $14^{\text {th }}$ century Clear Mirror gives a quite detailed description of the episode. The important chronicle of the $5^{\text {th }}$ Dalai Lama in the $17^{\text {th }}$ century has a concise rendering, omitting important motifs. The Testimony of $B a$, originally composed in the $9^{\text {th }}$ century (surviving in several, somewhat later versions) is our earliest testimony; although short, it preserves important elements that were later not fully understood.

\section{A) The Clear Mirror}

The first text of our analysis will be the $20^{\text {th }}$ chapter of The Clear Mirror Royal Genealogy $y^{6}$, a chronicle of the world but especially of Buddhism in Tibet, writ-

\footnotetext{
${ }^{4}$ Name variants are Khri-song Lde-btsan, or Khri-song Lde'u-btsan.

${ }^{5}$ Concerning Khri-srong Lde-btsan's role in Tibetan politics, see Schaik 2011: 27-44.

${ }^{6}$ Rgyal-rabs gsal-ba'i me-long.
} 
ten around 1350 by the powerful politician and religious leader Sa-skya Bsodnams Rgyal-mtshan. ${ }^{7}$ The full story runs as follows: ${ }^{8}$

One year later, Kyimshing Kongjo learned she was pregnant with an infant prince, but a senior consort named Nanam Zang Zhiteng grew jealous and falsely declared, 'I also carry the king's successor'. When Trisong Detsen was born to the Chinese princess in the Iron-male-horse Year [730] at Dragmar, Nanam Zang came to her, and although she showed her great affection, ${ }^{9}$ she stole ${ }^{10}$ the princess's infant and announced deceitfully, 'This baby was born to me!'

Kyimshing Kongjo exposed her breasts, uttered lamentations and wept, but Nanam Zang refused to yield the child. ${ }^{11}$ The Chinese princess therefore informed the ministers and petitioned the king, ${ }^{12}$ but Nanam Zang rubbed upon her own breasts an ointment that caused the milk to flow, and having done so, she too showed the ministers. They became filled with doubt, not knowing who was the true mother. As Kyimshing Kongjo's baby had been stolen by the senior consort, and as she could not withstand the older woman's aggression, ${ }^{13}$ she had no further course of action.

Kyimshing Kongjo then thought to herself, 'It is difficult for the baby to benefit me at this juncture. I shall therefore destroy this land of Tibet!' She studied the geomancy of the mountains, and in order to sever the royal line of descent, she drew a wheel with her own menstrual blood ${ }^{14}$ on the summit of the king's life-force mountain, which resembled a snow-lion leaping into the sky. The princess then concealed the cipher beneath a stupa. Next, in order to prevent the advent of intelligent ministers, she blocked the 'nose' of the ministers' life-force mountain with molten bronze, and severed the conjoined 'tails' of Tagri, 'Tiger Mountain', and Sengri, 'Snow-lion Mountain'. In order to cause famine, she

7 On the background of The Clear Mirror see Szegedi 2013b: 270, Szegedi 2013a: 80-82.

8 Taylor - Yuthok 1996: 226-229. Their translation may be compared to Sørensen 1994: 358-362. RGM: 199-201. I will give some alternative interpretations in footnotes.

9 Shin-tu blo nye-ba-ltar byas-nas: "affecting very amicable" (Sørensen 1994: 358). This may be connected to the motif of the demoness hiding her identity as seen in the Sba-bzhed and Mahommagga versions of the story.

${ }_{10}$ Rgya-mo'i bu-chung phrog-ste: she seized/grabbed/took forcibly/snatched. See later in the Sba-bzhed's context.

${ }^{11}$ Bu-chung ma btang-bas: didn't let go her hold of the baby. - This suggests the 'pulling the child' motif, cf. fn. 13, and see later in the Sba-bzhed's context.

${ }_{12}$ Rgyal-po-la zhus-pas: She (or: they) asked the king [for decision].

${ }_{13}$ (... phrogs-pas/) dbang-shed-mos ni ma thub/ byed-thabs med-par song-ngo: She, having been unable to cope with [her] power and physical strength, and having no means of action, went away.

${ }_{14}$ Mngal-khrag-gis 'khor-lo bris (RGM 199-200): She drew a circle with her postpartum blood. - Note that this feature supports the suggested maternal rite interpretation. 
cut the 'roots' of Mena Mountain at Yarlung, which resembled tender shoots of rice, and in order to bring leprosy to Tibet, she removed the 'bill' of Mangkhar Mountain, which resembled a great eagle soaring in the sky.

When she had accomplished all this, as it was her son's first birthday, the families of the two consorts were invited from China and Nanam to attend a festivity to celebrate the boy's first steps. They duly reached Tibet from their respective lands, and the people of Nanam brought gifts, ornaments, clothing and garlands of flowers for the little boy's amusement.

The king sat upon his golden throne in the centre of the royal palace with the family of Nanam on his right and the family of the Chinese princess on his left. His father, the king, adorned the boy with many ornaments, placed a golden cup filled with rice-beer in his son's hands, and said,

My only son, born of two mothers,

Although small, your body is the manifestation of a deity.

Place this vessel, a golden cup filled with rice-beer,

Into the hands of your uncle.

By this we will determine who is your true mother.

So saying, he offered prayers and sent his son, who was just able to walk, on his way. Taking the cup, the boy set off. Although the people of Nanam enticed him with clothes, ornaments and garlands of flowers and beckoned to him, the child ignored their exhortations and ${ }^{15}$ went instead to the Chinese, to whom he gave the golden cup and addressed these words:

I, Trisong Detsen, am a nephew of the Chinese.

I do not understand my uncles from Nanam. ${ }^{16}$

With that, he sat down in the lap of his Chinese uncle. ${ }^{17}$ His mother was overjoyed and said:

By the virtue of good karma accrued in former lives,

To me, a girl who came from China,

The son of a matchless king was born.

But on account of my adverse karma,

This boy who was born to me was stolen by another.

Ignoring my honest pleas,

Although I showed my breasts, the infant was not returned.

15 The Tibetan text in footnote 17 starts from this point.

16 Sna-nam zhang-gi don mi 'tshal - I have no deal with an uncle of Sna-nam.

17 Rgya-rnams-kyi rtsar byung-ste/ gser-skyog Rgya-la gtad-nas 'di-skad zer-ro/ nga Khrisrong Lde-btsan Rgya-tsha yin// Sna-nam zhang-gi don mi 'tshal// zer-te/ zhang-po Rgya'i pangdu song-ngo// 
The body and mind of this Chinese princess were seared with pain, And being unable to bear the suffering of mental fury, I undermined the beneficial geomantic influence of the mountains of Tibet.

Today, the sun of the deity has arisen:

Son, you recognised your uncle.

You mother's body and mind repose in happiness.

The decline of the geomantic influence of the mountains of Tibet Will be reversed without harm.

Thus she spoke. Knowing that the boy was indeed the son of the Chinese princess Kyimshing Kongjo, a great celebration was held.

\section{B) Melodies of the Spring Queen}

The Annals of Tibet, Melodies of the Spring Queen ${ }^{18}$ is a historical work written by Ngag-dbang Blo-bzang Rgya-mtsho, the 5th Dalai Lama (ruled 1617-1682), one of the greatest Tibetan authorities. He tells the story concisely:

At that time, (another of) the king's consorts, (called) rNam-sNan bZa', ${ }^{19}$ said that she had borne the king's son in her womb. (So saying), she stole the Chinese consort's son and pretended that he had been born to her. The king and his ministers had their doubts but did not dare to decide the matter legally. The Chinese consort, being dissatisfied, damaged some of the favourable (reports on the) "examination of the land" of Tibet.

Not long afterwards, at the ceremony of setting the son's feet (on the ground, for the first time), (sitting) in the middle of the two queens' friends and relatives and his ministers and subjects, the king placed a golden cup, filled with ricewine, in the hands of his son, saying,

Son, place this golden cup, filled with wine,

In the hands of your maternal uncle.

We shall then be sure who your mother is.

The son placed the precious cup in the hands of the Chinese, saying,

I, KHri-Sron IDe-bTSan, am a grandson of the Chinese (emperor).

(The name) rNam-sNan has no meaning whatsoever for me.

${ }_{18}$ Bod-kyi deb-ther dpyid-kyi rgyal-mo'i glu-dbyangs

${ }^{19}$ Rnam-snang Bza': Lady Splendour (Namnang) is a later, standardized, theophoric form of the name Sna-nam (Nanam). 
The Chinese consort was delighted. [...]

She is said to have repaired the (reports on the) "examination of the land," which she had damaged previously. ${ }^{20}$

\section{C) Testimony of Ba}

The so-called Testimony of $B a$ is in fact an English title given to at least three different, but closely related texts. They are different royal narratives ( $b k a$ '-mchid) written by members of the $\mathrm{Ba}$ (spelled Sba/Dba'/Rba) clan probably during the $8-9^{\text {th }}$ centuries, and which were reworked in the $11-14^{\text {th }}$ centuries. This corpus is a very precious source for studying Tibetan history, being the earliest documents containing histories of the first spread of Buddhism in Tibet, especially of Khri-srong Lde-btsan's reign. The works are traditionally attributed to Sba/Dba' Gsal-snang, a minister of Khri-srong Lde-btsan. The Dba' version is supposed to be earlier than the Sba version, but the relationship of the texts is not fully clear. $^{21}$

\section{C1. The Dba'-bzhed chronicle}

The entire story is lacking in this version of the work. ${ }^{22}$ We can identify the chronological locus of the event known from the other sources, but the description of the birth of Khri-srong Lde-btsan is absolutely absent. His parents are dead, and the 13 year-old Khri-srong ascends the throne:

${ }^{20}$ Zahiruddin 1995: 50. - Tib. dus der rgyal-po'i btsun-mo Rnam-snang Bzas kyang "Rgyalpo'i sras shig mngal-du chags-pa" skad zer-nas Kong-jo'i sras phrogs-te khong-rang-las skyes-pa-ltar byas-pas/ rje-blon-rnams the-tshom-du gyur-pas zhal-lce gcod-pa'i spobs-pa ma byung-zhing/ Kong-jo yid ma rangs-par Bod-kyi sa-dpyad bzang-ba 'ga'-zhig nyams-su bcug [/] mi ring-bar sras zhabs-'dzugs-kyi dga'-ston-la btsun-mo gnyis-kyi pha-ming dang blon-'bangsrnams 'tshogs-pa'i dbus-su/rgyal-pos 'bras-chang-gis bkang-pa'i gser-gyi phor-pa sras-kyi lag-tu gtad-del snod gser-skyogs chang-gis gang-ba 'di// bu khyod-rang-gi zhang-po'i lag-tu thod// ma gang yin-gyi yid-ches de-la byed// gsungs-pas/ sras-kyis rin-po-che'i phor-pa Rgya-rnams-kyi lag-tu gtad-nas/ nga Khri-srong-lde-btsan Rgya-tsha yin// Rnam-snang gang-gi don mi 'tshal// gsungs-pa dang/Kong-jo yid rab-tu dga'-ste/ gsungs-pa dang/Kong-jo yid rab-tu dga'-ste/ tshe sngon-ma'i las-kyi 'phen-pa-yis// nga Rgya-nas 'ongs-pa'i bu-mo-la// rje 'gran-med rgyal-po'i sras shig 'khrungs//zhes-sogs-kyi gtam smras-nas/sngar sa-dpyad nyams-su bcug-pa-rnams bsos skad/ (Ngag-dbang 1991: 51-52).

${ }^{21}$ Some fragments of the probably earliest manuscript of 31 folios has been found in the Dunhuang caves in 1997. For further information and bibliography see Martin 1997: 23, Kapstein 2000: 23-37, Schaik - Iwao 2008, Szegedi 2013b: 275-278, 281, Tsumagari 2013, Doney 2021 a.

${ }^{22}$ Wangdu - Diemberger 2000: 34-35, Gonkatsang - Willis 2021: 108-109. 
Then the bTsan po and Ong co passed away. During the reign of the son [of Khri 1De gtsug btsan], Khri Srong lde btsan, as soon as he took over the governance of the kingdom at the age of $13,[\ldots] .{ }^{23}$

\section{C2. The Sba-bzhed chronicle}

It is quite significant that in some recensions of the Testimony of $B a,{ }^{24}$ we can find a rather concise description of King Khri-srong's origins.

When the king went to the 'Phang-thang in Yarlung to see his new-born child, Kong-jo's [the Chinese queen's] son was forcibly taken by Sna-nam Bza' Bzhistengs, saying: "This was born to me". In order that all ministers could examine it, they laid down the child into a Tang [i.e. Chinese] divination hole, ${ }^{25}$ and made [them] do "who [can] get the child?". Kong-jo grasped him first:;6 Bzhi-stengs, thinking "if he dies, dies", forcibly drew him. So Kong-jo, fearing that the child may die, loosened her grasp: "Although he is mine, but you are a demon!" - she let him go. It was recognised that the child is Kong-jo's.

A year later the festival of the first steps of the child was organised. The people of Sna-nam each held a small cloak of brocade in their hands, and said: "come to the lap of your maternal uncle." The prince said:

"I am Khri-srong Lde-btsan, offspring of the Chinese,

What shall I do with an uncle of Sna-nam?"

Saying so, he went to the lap of the Chinese. He gave his name himself. ${ }^{27}$

${ }^{23}$ Wangdu - Diemberger 2000: 35. Tib. [4r5-6]: Btsan-po dang Ong-co ni sku-'das-so// sraspo Khri-srong Lde-btsan-gyi sku-ring-la/ dgung-lo bcu-gsum son-pa-na* chab-srid phyag-tu bzhes ma-thag-tu (...). Gonkatsang - Willis 2021: 108. [4r5-6] (*lon-pa-na).

${ }^{24}$ Concerning the extant recensions cf. Doney 2021b: 6-17. Doney 2013 gives a comparative analysis of Bashe tradition with some Nyingma chronicles. This is an important contribution to the interpretation of the locus examined here.

${ }^{25}$ Thang-rtsis-kyi bu-gar-Thang-rtsis is my emendation of thang-tshigs in the edition, based on Nyang-ral 1980:169. It reads: blon-po kun-gyi[s] thang-rtsis-kyi bug-par bu bzhag-nas mo gnyis sus thob byed-du bcug-pas - "As all ministers laid down the child into a divination hole, and made the two women do 'who [can] get [him]' [...]". For the interpretation as 'Chinese divination hole' cf. e.g. Namgyal 2015. Stein (1961: 4) reads thang-rtsigs.

${ }^{26}$ Or: at the front (sngon-la).

27 Sba-bzhed, pp. 4-5., my translation. Tib. rgyal-pos Yar-lung 'Phang-thang-du sras bltamspa gzigs-su byon-pa'i tshe | Kong-jo'i bu Sna-rnam (nam) bza' Bzhi-stengs-kyis phrogs-nas 'di nga-la skyes-pa yin zer | der blon-po kun-gyis brtag-par bya-ba'i phyir | thang-tshigs-kyi buggar bu bzhag-nas bu su thob byed-du bcug-pas | Kong-jos sngon-la zin-pa Bzhi-stengs-kyis shina'ang shi snyam-te phrogs-pas | Kong-jos bu shi dogs-nas lhod-btang-ste | yin dang nga'i yin-te dri (dre)-mo khyod zer-nas btang | bu Kong-jo'i yin-par shes | lo gcig lon-tsa-na zhabs 
In this narrative the supposedly historic event receives a fabulous tone. It resembles a mystery play or fairy tale; however, some degree of truth can be ascribed to a narrative of this kind as well. Although the narrative may not depict an ordinary event, it could represent a considerably important custom or rite that had been alive formerly, but whose memory had faded by the time of the chroniclers.

\section{History and legend}

It is clear that what is at stake in the story is not motherly affections but power relations: which group can control the current and the future king. The great clans, 'Bro, Sna-nam, Mgar, 'Khon, Chog, Rma' etc. families were involved in the process of Tibet's first conversion to Buddhism. Their affiliations with several tribes in the region (e.g. with Zhangzhung, Khotanese and Chinese communities) made up a wide, "international" alliance. The leaders of these clans and their descendants have remained important players in Tibetan history for many centuries. Family relationships had great importance from the beginning in the formation of the Tibetan power structure towards a theocratic state.

One of the most significant relationships was the uncle-nephew connection; here 'uncle' refers primarily to the maternal uncles (zhang). The most influential families ran the great monasteries with the surrounding territories as feudal manors. Senior leaders of the clans occupied the position of state ministers (zhang-blon, 'uncle minister') who were often able to seize the main power, controlling the state instead of the young emperors. Nephews inherited from their maternal uncles not only their secular powers but also spiritual leadership in the religious sphere.

So the situation is clearly historically realistic. Nonetheless, it is important to recognise that most key elements of the story are not and cannot be historically accurate. Is it conceivable that people would be unable to easily decide which of two young ladies has recently given birth? Would a king leave such an important decision to a one-year old baby? Would he be able to deliver his judgment in verse? How is it possible to recognise one's Chinese uncle whom one has never seen before?

\footnotetext{
'dzugs-pa'i dga'-ston byas-te | Sna-nam-pa-rnams ber chung-ngu re lag-na thogs-nas zhang-po'i pang-du shog zer | rgyal-bu na-re | Khri-srong Lde-btsan Rgya-tsha lags | Sna-nam zhang-gi ci bgyi 'tshal | gsungs-nas Rgya'i spang (pang)-du song-bas | ming yang rang-gis btags-so | The versions given in brackets are found in the contemporary Chinese Tibetan edition (cf. Sba-bzhed) which is a contaminated edition. The story is briefly rendered in Stein 1961: VII., Kapstein 2000: 26-28. Doney (2013: 23-24) gives alternative readings and a partial translation, too. The episode of the "pulling test" he omits. They all interpret the situation as if the child had gone to his mother.
} 
Comparing the three Tibetan historical narratives given above, we can see that they do share a set of motifs; some are clear, others are faded or hidden, and the three versions handle the motifs in a different manner. Herein I will highlight only some of the more obvious parallels/analogues in order to ascertain the function of these motifs and to clarify the origin of our narratives. All these elements belong recognisably to a huge set of common archaic mythological motifs, surviving to the present day in ancient texts and in current folk-tales. ${ }^{28}$ Three of the motifs will be analysed by comparing them to other, and at times, quite distant variants.

\section{Who is the mother?}

To start with the best known, although perhaps the most absurd motif: identifying the true mother (where two females claim the baby) is, of course, the focus of the judgment of Solomon. ${ }^{29}$

Then two prostitutes came to the king and stood before him.

"If it please you, my lord," one of the women said, "this woman and I live in the same house, and while she was in the house I gave birth to a child. Now it happened on the third day after my delivery that this woman also gave birth to a child. We were alone together; there was no one else in the house with us; just the two of us in the house. Now one night this woman's son died; she overlaid him. And in the middle of the night she got up and took my son from beside me while your servant was asleep; she put him to her breast and put her own dead son to mine. When I got up to suckle my child, there he was, dead. But in the morning I looked at him carefully, and he was not the child I had borne at all."

Then the other woman spoke. "That is not true! My son is the live one, yours is the dead one"; and the first retorted, "That is not true! Your son is the dead one, mine is the live one." And so they wrangled before the king.

"This one says," the king observed, "My son is the one who is alive; your son is dead,' while the other says, 'That is not true! Your son is the dead one, mine is the live one.' Bring me a sword," said the king; and a sword was brought into the king's presence.

"Cut the living child in two," the king said, "and give half to one, half to the other."

${ }^{28}$ Folk-tales preserve archaic myths and epic material, see e.g. on the Kalmyk folk material Birtalan - Rákos 2002: 79-81.

291 Kings 3.16-28, quoted from Jones 1968: 364-365. 
At this the woman who was the mother of the living child addressed the king, for she burned with pity for her son. "If it please you, my lord," she said, "let them give her the child; only do not let them think of killing it!" But the other said, "He shall belong to neither of us. Cut him up."

Then the king gave his decision. "Give the child to the first woman," he said, "and do not kill him. She is his mother."

The Biblical story is remarkably successful in making the problem credible: here both women have recently given birth; although the motivation for stealing the baby is far from obvious. As Hugo Greßmann showed already in 1907, there are many parallels to this story worldwide. Closer to Tibet, the story is known from the Chinese Chalk Circle (Hui Lan Ji 灰闌記), a four-act drama by the $14^{\text {th }}$ century classical poet Li Qianfu 李潛夫. It is also present in the Indian Buddhist tradition, at least a millennium earlier. In the Mahā-Ummagga-Jātaka ('The birth story of the Great Tunnel'), the Buddha in an earlier life plays the role of Solomon. ${ }^{30}$

A certain woman took her son and went down to the sage's tank to wash her face. After she had bathed her son she laid him in her dress and having washed her own face went to bathe. At that moment a female goblin saw the child and wished to eat it, so she took hold of the dress and said, "My friend, this is a fine child, is he your son?" Then she asked if she might give him suck, and on obtaining the mother's consent, she took him and played with him for a while and then tried to run off with him. The other ran after her and seized hold of her, shouting, "Whither are you carrying my child?" The goblin replied, "Why do you touch the child? he is mine." As they wrangled they passed by the door of the hall, and the sage, hearing the noise, sent for them and asked what was the matter. When he heard the story, although he knew at once by her red unwinking eyes that one of them was a goblin, he asked them whether they would abide by his decision. On their promising to do so, he drew a line and laid the child in the middle of the line and bade the goblin seize the child by the hands and the mother by the feet. Then he said to them, "Lay hold of it and pull; the child is hers who can pull it over." They both pulled, and the child, being pained while it was pulled, uttered a loud cry. Then the mother, with a heart which seemed ready to burst, let the child go and stood weeping. The sage asked the multitude, "Is it the heart of the mother which is tender towards the child or the heart of her who is not the mother?" They answered, "The mother's heart." "Is she the mother who kept hold of the child or she who let it go?" They replied, "She who let it go."

${ }^{30}$ Sub-story 5 in Jātaka No. 546, quoted from Cowell - Rouse 1907: 163. Kapstein (2000: 30-36) notices the parallelism of the queens' fight with Solomon's judgment and the Mahä-Ummagga-Jätaka. He supposes that this type of judgment may be a common motif of stories wandering along the Silk Road. 
"Do you know who she is who stole the child?" "We do not know, sage." "She is a goblin, - she seized it in order to eat it." When they asked how he knew that he replied, "I knew her by her unwinking and red eyes and by her casting no shadow and by her fearlessness and want of mercy." Then he asked her what she was, and she confessed that she was a goblin. "Why did you seize the child?" "To eat it." "You blind fool," he said, "you committed sin in old time and so were born as a goblin; and now you still go on committing sin, blind fool that you are." Then he exhorted her and established her in the five precepts and sent her away; and the mother blessed him, and saying, "May'st thou live long, my lord," took her son and went her way.

There are several versions of the motif in the Tibetan Buddhist canonical literature. ${ }^{31}$ It can be found embedded in the Sutra of the Wise and the Foolish ('Dzangs-blun zhes-bya-ba'i mdo) $)^{32}$ as part of the folk-tale story of the householder Stickholder (Dbyig-pa-can).

There were also there two women who disputed the possession of a young boy. When they petitioned the king for a decision, he wisely said to them: 'Each of you take one of the boy's arms and pull. Whoever is strongest will have the boy.' One woman had no thought for the child's life and pulled hard. The other woman, fearing for the child, was gentle. Seeing this, the king said to the first woman: 'This is not your child. It belongs to the woman who was gentle with him.' The mother then took the child and departed. ${ }^{33}$

Another canonical version from the Kanjur is even more successful than the Biblical version in making the problem credible: here the judgment occurs some years after the birth of the child and there is a logical explanation for the exchange of mothers.

There was a householder in a hill-village who, after he had married in his own rank, remained without either son or daughter. As he longed earnestly for a child, he took unto himself a concubine. Thereupon his wife, who was of a jealous disposition, had recourse to a spell for the purpose of rendering that woman barren. But as that woman was quite pure, she became with child, and at the end of nine months bare a son. Then she reflected thus: "As the worst of all enmities is the enmity between a wife and a concubine, and the stepmother will be sure to seek

31 The Tibetan Canon is, of course, a collection of translations, mostly from Indian languages, but also many from Chinese etc. sources.

${ }^{32}$ In the critical edition: Tóth 1996: 308. - I am grateful to Erzsébet Tóth for a careful reading of this paper and several valuable suggestions.

33 Frye 1981: 213. This is a translation of the Mongolian version, since there is no English translation of the Tibetan. A Hungarian translation is available: Halászné Róna 1999: 110. 
for a means of killing the child, what ought my husband, what ought I to do? As I shall not be able to keep it alive, I had better give it to her."

After taking counsel with her husband, who agreed with her in the matter, she said to the wife, "O sister, I give you my son; take him." The wife thought, "As she who has a son ranks as the mistress of the house, I will bring him up."

After she had taken charge of the boy the father died. A dispute arose between the two women as to the possession of the house, each of them asserting that it belonged to her. They had recourse to the king. He ordered his ministers to go to the house and to make inquiries as to the ownership of the son. They investigated the matter, but the day came to an end before they had brought it to a satisfactory conclusion. In the evening they returned to their homes. Viśākhā again questioned Mrgadhara, who told her everything. Viśākhā said, "What need is there of investigation? Speak to the two women thus: 'As we do not know to which of you two the boy belongs, let her who is the strongest take the boy.' When each of them has taken hold of one of the boy's hands, and he begins to cry out on account of the pain, the real mother will let go, being full of compassion for him, and knowing that if her child remains alive she will be able to see it again; but the other, who has no compassion for him, will not let go. Then beat her with a switch, and she will thereupon confess the truth as to the whole matter. That is the proper test." Mrgadhara told this to the ministers, and so forth, as is written above, down to the words, "The king said, 'The Champā maiden is wise.' ",34

In all the Indian, Chinese, and Tibetan versions we find the softer test of pulling the child instead of the cruel Solomonic idea of cutting the child in two (to which, quite absurdly, the non-mother agrees). In the Clear Mirror and in the second part of the story in the Testimony of Sba it is further softened to calling the child to the maternal party. Still, it is patently obvious that we find here not a historical event but an archetypical international legendary motif.

\section{Stealing the baby}

A second, seemingly closely related, yet in fact quite independent, motif is stealing the newborn baby from the queen in order to gain influence over the king. We find it in many fairy tales, where the rivalry of co-wives is absent, since in European folklore legal polygamy is, naturally, unknown. Therefore, the queen is killed or removed in some other way, and the evil witch's daughter takes her position. In the Russian tale of Burenushka, the red cow we find a compressed version: ${ }^{35}$

\footnotetext{
34 Schiefner - Ralston 1906: 120-121.
}

35 Afanas'ev 1945: 143. 
Princess Maria gave birth to a son. She wanted to visit her father, and went to his house with her husband. Her stepmother turned her into a goose and disguised her elder daughter as Prince Ivan's wife. Prince Ivan returned home. The old tutor of the child got up early in the morning, washed himself very clean, took the baby in his arms, and went to an open field, stopping near a little bush. Geese came flying, gray geese came. "My geese, gray geese! Where have you seen the baby's mother?" "In the next flock." The next flock came. "My geese, gray geese! Where have you seen the baby's mother?" The baby's mother jumped to the ground, tore off her goose skin, took the baby in her arms, and nursed him at her breast, crying: "I will nurse him today, I will nurse him tomorrow, but the day after I will fly beyond the forests dark, beyond the mountains high!"

In a Grimm version, Little Brother and Little Sister, the transformation to a water-bird element is replaced by the drowning, i.e. killing with water, of the mother. ${ }^{36}$

As time went on, the Queen had a pretty little boy, and it happened that the King was out hunting; so the old witch took the form of the chambermaid, went into the room where the Queen lay, and said to her, "Come, the bath is ready; it will do you good, and give you fresh strength; make haste before it gets cold."

The daughter also was close by; so they carried the weakly Queen into the bath-room, and put her into the bath; then they shut the door and ran away. But in the bath-room they had made a fire of such deadly heat that the beautiful young Queen was soon suffocated.

When this was done the old woman took her daughter, put a nightcap on her head, and laid her in bed in place of the Queen. ...

But at midnight, when all slept, the nurse, who was sitting in the nursery by the cradle, and who was the only person awake, saw the door open and the true Queen walk in. She took the child out of the cradle, laid it on her arm, and suckled it. Then she shook up its pillow, laid the child down again, and covered it with the little quilt. And she did not forget the roebuck, but went into the corner where it lay, and stroked its back. Then she went quite silently out of the door again. The next morning the nurse asked the guards whether anyone had come into the palace during the night, but they answered, "No, we have seen no one."

She came thus many nights and never spoke a word: the nurse always saw her, but she did not dare to tell anyone about it. When some time had passed in this manner, the Queen began to speak in the night, and said-

"How fares my child, how fares my roe?

Twice shall I come, then never more."

${ }^{36}$ Grimm - Grimm 2013: 75. 
The nurse did not answer, but when the Queen had gone again, went to the King and told him all. The King said, "Ah, heavens! what is this? Tomorrow night I will watch by the child." In the evening he went into the nursery, and at midnight the Queen again appeared and said-

"How fares my child, how fares my roe?

Once will I come, then never more."

And she nursed the child as she was wont to do before she disappeared. The King dared not speak to her, but on the next night he watched again. Then she said-

"How fares my child, how fares my roe?

This time I come, then never more."

Then the King could not restrain himself; he sprang towards her, and said, "You can be none other than my dear wife." She answered, "Yes, I am your dear wife," and at the same moment she received life again, and by God's grace became fresh, rosy, and full of health.

The much shorter presentation in The Six Swans is perhaps the most archaic; here it is the king's mother that removes the unwanted competitor, which seems to be a version of the Oedipal motif. ${ }^{37}$

The King, however, had a wicked mother who was dissatisfied with this marriage and spoke ill of the young Queen. "Who knows," said she, "from whence the creature who can't speak, comes? She is not worthy of a king!" After a year had passed, when the Queen brought her first child into the world, the old woman took it away from her, and smeared her mouth with blood as she slept. Then she went to the King and accused the Queen of being a man-eater. The King would not believe it, and would not suffer any one to do her any injury. She, however, sat continually sewing at the shirts, and cared for nothing else. The next time, when she again bore a beautiful boy, the false step-mother used the same treachery, but the King could not bring himself to give credit to her words. He said, "She is too pious and good to do anything of that kind; if she were not dumb, and could defend herself, her innocence would come to light." But when the old woman stole away the newly-born child for the third time, and accused the Queen, who did not utter one word of defence, the King could do no otherwise than deliver her over to justice, and she was sentenced to suffer death by fire.

It is remarkable, that in several of the stories the ability to suckle the baby is the mark of the true mother, just as we find it in The Clear Mirror.

37 Grimm - Grimm 2013: 272. 


\section{Sitting on the lap}

Interestingly, the baby Khri-srong Lde-btsan is not asked to identify his mother but rather his maternal uncle. He does so by handing over the goblet of rice-vine as requested; as a seemingly insignificant addition, he also sits on his uncle's lap.

As Ruzsa (2016) ${ }^{38}$ noticed, the complex motif of the new ruler choosing his family by sitting on the lap of a male representative can be found in the Indian legend of Sunahiśepa, the legend narrated at the rājasūya ceremony, i.e. at the consecration rite of the heir apparent. Following his reconstruction, we can see that our apparently innocent and endearing story of a baby is, in fact, a remnant of an archaic rite.

As Ruzsa, following Frazer, convincingly demonstrated, the taking of a child onto the lap is a widespread ritual of adoption, symbolising new birth into the new family. This interpretation fits our story perfectly well. Following Ruzsa's observation, we can add several further parallelisms between the two stories. Viśvāmitra, who adopts Śunahśepa is his maternal uncle (mātula) in the version told in the Rammayana. And in the oldest version, in the Aitareya-äranyaka, similarly to Khri-srong Lde-btsan's story, two parties contend for the child, although here they are males: the father, Ajīgarta and Viśvāmitra. Moreover, both try to 'invite' the child, to lure him to themselves, and he chooses. His decision is not a private affair: he changes not only his family but also his clan. In both cases the sitting on the lap happens at a large ceremony, specially convoked with the child in the centre. In the Tibetan version, since Khri-srong Lde-btsan is but one year old, it is apparent that the child's choice is not an act of free will but a kind of ordeal, a result of supernatural intervention. The context is also specifically ritual, a rite of passage: the feast of the first steps of the child (zhabs-'dzugs-kyi $d g a$ '-ston). Ruzsa has also reconstructed for the legend of Śunahiśepa (and indirectly for the stories of Isaac and even Snow White) a rite of passage interpretation - originally it was a special variant of puberty initiation: the consecration of the heir apparent, the ritual initiation of the future shaman-king. ${ }^{39}$

As seen above, the main motifs of the Tibetan 'historical' narrative can be considered analogous to the motifs in the Indian material, and therefore the conclusions drawn from the latter can also be transferred here. Therefore, it seems plausible to suggest that the Tibetan chronicles also show fragmented traces of a rite of passage which are no longer understood: an initiation rite and royal consecration.

\footnotetext{
${ }^{38}$ In an earlier Hungarian version (Ruzsa 2015), he also gives a translation of the whole story.

39 The shamanistic element is elaborately discussed in Ruzsa 2018.
} 


\section{The main motifs}

Comparing the structural motifs of Khri-srong Lde-btsan's legend in the attested sources a clear "storyboard" comes into view. The earlier the source text, the more complete the dramaturgy. It has the most complete form in the Sba-bzhed, despite its most concise and obscure style. There the ritual events are separated into two acts. The birth of the child is immediately followed by the "chalk circle" test, or rather "pulling test". At the age of one, the ceremony for choosing the family takes place.

On closer inspection, The Clear Mirror also shows traces of the twofold ritual. The purpose of the "first steps" ordeal is expressly to choose a family. Although the previous issue of breastfeeding is seemingly just about the Snanam queen's power tricks, it is in fact a maternity test. The "pulling test" in Sba-bzhed serves to decide the true mother; structurally it is equivalent to the "breast-test". Noticeably, this event is rendered in more detail than the "second act", and thus it obviously refers to an independent and significant test-ceremony. Only the woman who will be able to draw the child from the hole is the one who gave birth to him. This magical verification is analogous to the "breast-test": the woman who is able to suckle the child herself is evidently the one who had born him.

The "pulling test" closely resembles the famous "chalk circle test". However, this is not a witty court decision to end some laywomen's squabble, but a life-and-death struggle. Considering the parallel in the Mahä-Ummagga-Jātaka, where the non-mother is a yaksini who wants to eat the child, we infer that here, too, the story represents a struggle between good and evil. The evil power is identified by the spell: "You are a demon", uttered by the mother (or the shaman-king? The participants of the apparently ritualistic dialog are not clearly identified). Geomancy as magic performed by the true mother in the later texts, and the "You are a demon" sentence as a revealing spell seem to be functionally equivalent. The "breast test" and the "pulling test" on the one hand, and the spell unmasking the demon and geomancy on the other, are thus parallel elements.

The mother's recognition of the Sna-nam woman as a non-human, strange, demonic enemy also parallels the child's identification of the maternal uncle and his relatives as representatives of a familiar, protecting power.

In the Buddhist Jătakas there is always a moment when the Buddha identifies the key agents of the story with the individuals involved in the "real-life" situation where the teaching occurs. To find the new Dalai Lama or another reincarnated person (Tib. sprul-sku), a set of tests are applied, among them recognising the personal items of the previous spiritual leader. When, during the first-steps ceremony the one-year-old prince is being enticed by his true 
and sham relatives, it further reminds us of the demons of good and evil in the "intermediate existence" (bar-do) calling the dead soul to the next birth. Some conception of rebirth may be supposed as a background for the "recognizing" motif in the family-choosing rite. This is consistent with what Ruzsa has shown of the connection between adult initiation and sitting on the lap as a symbol of rebirth in India.

The layout of the scene of the "pulling test" is also remarkable. I think that the central motif is the scene's centre itself: the "hole" or "pit". What has the phrase "divination hole" to do with the situation described in the text? To my mind, pulling the child from a ritually empowered hole or circle is a symbolic act, related to life's limits. To be during birth is a liminal situation, an intermediate stage. The women, Life-mother against Death-demon, meet and fight for the child. The title of the Mahä-Ummagga-Jātaka, 'The birth story of the Great Tunnel' may be distantly related to the same symbolic image. This seems to be a double-sided symbol. On the one hand, it's about the dangerous process of birth: it involves the quasi-magical maternal power, and there is the risk of death - losing the child and/or the mother. On the other hand, pulling the child from a ritual pit or circle may refer to the border-passage between the World of Living beings and the Other-/Underworld of dead spirits as it is described in so many myths and folktales worldwide. Roughly speaking, the "great tunnel" or the "divination hole" refers to the birth canal literally, and figuratively the passageway from death to birth and vice versa. ${ }^{40}$

Considered this way, the "pulling test" seems to have an extremely archaic and rather shamanistic cultural background.

\section{Traces of female life-cycle rituals}

It cannot go unnoticed that the issue under investigation involves the ritually most important role of women: childbirth and breastfeeding. The underlying motif of the first rite ("pulling the child from the hole") seems to be the fear of losing the newborn child - an archetypal, universal human condition. The burden of this is mainly on women. Being concerned with giving birth and maternal family relations, the pseudo-historical narratives depicted above appear to be connected with matriarchal ${ }^{41}$ traditions.

${ }^{40}$ It is possible further that the "divination hole" originally referred to the oracle bone divination. The hole or pit drilled into the bone might be marked with the sign of "child". In any case, the Tibetan narratives speak clearly about laying down the child into a pit or hole. In this way the figurative layout provides an opportunity for a fight in a tug-of-war manner.

${ }_{41}$ 'Matriarchal' here does not suggest a society ruled exclusively by women. It denotes a so- 
It seems that the complex of motifs, revealed so far through this paper's analysis and comparison, show signs of being the literary remnants of former customs and beliefs. Assuming that these narratives preserved the main structure and often even the characteristic wording of archaic myths, and that these myths were closely related to liminal rites (Skr. samskāra), we can try to reconstruct the fundamental form, meaning, and context of these rites. The story reveals some stages of a female fertility rite cycle. The "pulling-the-child" and "go-to-the-maternal-uncle" rites are most likely related elements of an archaic female ritual complex, which could certainly have had a function in a matriarchal socio-cultural environment for many centuries.

It is a nearly impossible task to find the roots and connections of these motifs. However, the key constituents of this long-obsolete rite may be related not only to elements of Indo-European and other initiation myths but also to a remarkable group of recent anthropological and sociographical data on some Tibetan ethnicities.

Recent studies of the Naxi Mosuo 纳西摩梭 and Zhaba 扎巴 peoples on the Eastern border of historical Tibet, in Western Sichuan and Yunnan Provinces may suggest some explanations for the wider original context of the rite. Féng (2010) draws attention to the fact that there are several ethnic groups scattered throughout the region, called the "Yí-Tibetan Corridor", ${ }^{42}$ among whom the characteristic elements of matrilineal customs still exist. He gives a detailed description of the marriage customs and family organization of the Zhaba, including economic aspects and other circumstances. Socially, maternal uncles play an extremely important role even in modern times. Based on the data collected by Michaud (2015) we can say that the situation is the same with the Mosuo people. That some peoples of the region have been able to preserve more elements of the earlier culture may be explained by the fact that their original religion was only much later supplanted by Buddhism than in other areas of Sino-Tibetan culture.

There is an ongoing project mapping small Himalayan languages approaching extinction, and also their mythologies. ${ }^{43}$ In the course of documenting oral traditions the French researchers noticed that the origin myths of several of these peoples show a marked matriarchal character. ${ }^{44}$

cial organisation where women have way more important social functions and responsibilities than in the well-known patriarchal model.

${ }^{42}$ Fei Xiaotong's term, see Féng 2010: 273.

${ }_{43}$ Parallel corpora in languages of the Greater Himalayas, http://himalco.huma-num.fr/index.htm (ANR HimalCo project).

${ }^{44} \mathrm{Cf}$. for example the researches at http://himalco.huma-num.fr/corpus/comparable/mythology.htm. Shi (2018), although describing in detail the historical movements of peoples in the area, surprisingly does not refer to matriarchal features. 
All these customs documented for certain ethnic peoples in Eastern Tibet and Nepal, and the inferences that can be drawn from them suggest the following remarks.

The special importance of maternal uncles is a feature of matriarchally organised societies. In contrast, polygyny (which is so central in our story) is characteristic of the leading elites of patriarchal communities. Considering this observation, we may notice another aspect of our story beyond its interpretation as an initiation rite. The maternity rite - as depicted in the Tibetan narratives - seems to occur in a patriarchal environment. The father brings his wife from another place (exogamy with patrilocal residence); belonging to the elite, he has several wives (polygyny). The point of departure is a typical patriarchal problem - the dominant man has no male descendant from his first wife. This constitutes a major difficulty for the inheritance of power (patrilineal descent and inheritance).

In our story, however, the focus is on the key factor in matriarchal communities: Who is the mother? Two women are fighting for the child. Although, viewed from the ruler's perspective, it does not matter who bears him a son. The only important thing is that he should have one. The fight of the mothers here has political significance, for the mother who owns the child has the greatest influence over the ruler. And this seems to be meaningful only in an environment where the mothers and their blood relatives form a strong and effective group that has the wealth and the network of connections necessary to realise their power ambitions.

Therefore, in addition to the external parallels and remaining within the limits of the attested material itself, the main motifs of the Tibetan story can be contrasted by way of the matriarchal versus patriarchal opposition. I think that such a rite as rendered in The Clear Mirror could have been practiced by aristocrats with patrilocal marriage and patrilineal inheritance - where being blessed with a child, especially a boy as successor, was a central issue; and they could afford the ceremony. In this way, the etiological myths, female fertility rites and marriage customs - all with fundamentally matriarchal origin - could have become connected to the initiation of the heir apparent in the context of the (throne) inheritance, despite the latter being a markedly patriarchal feature.

From these observations we may infer that the basis of the Tibetan historical narrative was not only a local inheritance crisis but also a source of real social tension and a change of historical dimensions. The conflict of the 'fatherly' and 'motherly' interests could express several real phenomena.

1. It could be an expression of the open conflict of two social groups with different structures (characterised by more matriarchal vs. patriarchal features). 
This could correspond to the conflict of the immigrant warlike patriarchal nomads and the indigenous settled matriarchal agriculturalists. ${ }^{45}$

2. The conflict of 'fatherly' and 'motherly' interests could express the tensions of an age of transition when several ethnic groups working on the formation of an empire appear in the area, organising a unified state from the loose network of tribal groups. In the process, the matriarchal organisation quite adequate for small local communities gets gradually pushed into the background, with the corresponding structures and rites breaking up, becoming secondary, or losing their meaning. Although the isolated elements of the fragmenting tradition can no longer fulfil their original function, nonetheless they are still retained in the memory of the community. In spite of the general expansion of patriarchal features (due partly to state organisation), the influence of consanguinity bonds (both maternal and paternal) is naturally preserved in kinship relations. The possibly dominant position of authority in the earlier structure: the position of the maternal uncle continues to be a significant power factor.

In support of the idea that a ritualistic interpretation of the story is required, some further facts may be noted. The Tibetan historical works report a lot of ritualistic events; prediction of the future, funeral and geomantic ceremonies, repression of hostile demons, revenge over the anti-Buddhist aristocrats, etc. The colophon of $D b a$ '-bzhed says explicitly that it is about a ritual: "The account of the food offering ritual is finished." ${ }^{46}$ The institution of the tshe rite is attributed to the Chinese princess Jincheng. ${ }^{47}$ Also, the narrative of how Jincheng takes revenge on the Tibetan ruler (she draws a circle with her postpartum blood) ${ }^{48}$ clearly shows the dominance of the maternal rite aspect in the birth-story of Khri-srong Lde-btsan. Several sources contain an account of how minister Ba Selnang became convinced that Buddhist teachings were true. This narrative has a clear theme of the rite affecting the bardo state, and that of the newborn child who recognize their previous life's possessions ${ }^{49}$ We could continue with a series of examples. So, we find that the broader context of the events described in the text includes various rites.

The initiation rite reconstructed from the story may have been part of a complex of rites that had been alive and effective presumably in a previous matriarchal environment. Due to social restructuring, the rite lost its function, and at the time of the writing of the chronicles only some isolated elements were

${ }^{45}$ For a culturally significant parallel, the incoming of the Aryans into agricultural (Dravidan?) India, see Ruzsa 2007.

${ }^{46}$ Gonkatsang - Willis 2021: 156-157. Tib. Zas-gtad-kyi lo-rgyus rdzogs-so (fol. 31v).

${ }^{47}$ Concerning the supposed Chinese roots of the tshe rite see Kapstein 2000: 38-39 (who follows Stein's argumentation).

48 Mngal-khrag-gis 'khor-lo bris-nas (RGM 199-200).

49 See Stein 1961: VIII., Kapstein 2000: 39. 
still known. These, however, were probably considered respectable constituents of the tradition, and the intellectuals producing historical records for the elite understood it as their duty to preserve these traditional accounts - at the same time attempting a rationalisation of the stories.

\section{References $^{50}$}

\section{Primary Tibetan sources and their translations}

Dba'-bzhed = Dba' Gsal-snang 2011. Dba'-bzhed. [Testimony of Dba'] Lhasa: Bod-ljongs bodyig dpe-rnying dpe-skrun-khang.

Doney, Lewis 2013. "Nyang ral Nyi ma ,od zer and the Testimony of Ba". Bulletin of Tibetology 1.49: 7-38.

Doney, Lewis (ed.) 2021a. Bringing Buddhism to Tibet: History and Narrative in the Dba'bzhed Manuscript. Berlin-Boston: De Gruyter. https://doi.org/10.1515/9783110715309

Doney, Lewis 2021b. "The Testimony of Ba: Literature and Exemplars". In: Doney, Lewis (ed.). Bringing Buddhism to Tibet: History and Narrative in the Dba' bzhed Manuscript. Berlin-Boston: De Gruyter, 3-23. https://doi.org/10.1515/9783110715309

Gongkatsang, Tsering - Willis, Michael 2021. "Text and Translation". In: Lewis Doney (ed.). Bringing Buddhism to Tibet: History and Narrative in the Dba' bzhed Manuscript. Berlin-Boston: De Gruyter, 102-157. https://doi.org/10.1515/9783110715309-007

Halászné, Róna Judit (tr.) 1999. "Botos gazda." [The householder Stickholder] In: Lengyel Zoltán - Szegedi Mónika (eds.) A bölcs és a balga. Tibeti buddhista történetek. [Sutra of the Wise and the Foolish. Tibetan Buddhist Stories] Budapest: Palatinus, 105-111.

Namgyal Golok (Mgo-log Rnam-rgyal, tr.) 2015. Spor-thang-rtsis-kyi gtsug-lag. [A Confucious astronomy] Pe-cin [Beijing]: Mi-rigs dpe-skrun-khang.

Ngag-dbang = Ngag-dbang Blo-bzang Rgya-mtsho 1991. Gangs-can yul-gyi sa-la spyod-pa'i mtho-ris (= Bod-kyi deb-ther Dpyid-kyi rgyal-mo'i glu-dbyangs. Rgyal-dbang lnga-pa chenmos brtsams-pa'i rgyal-blon gtso-bor brjod-pa'i deb-ther Rdzogs-ldan gzhon-nu'i dga'-ston Dpyid-kyi rgyal-mo'i glu-dbyangs zhes-bya-ba bzhugs-so.) [Annals of Tibet, Melodies of the Spring Queen] Lhasa-Beijing: Mi-rigs dpe- skrun-khang.

Nyang-ral Nyi-ma , Od-zer, Mnga'-bdag (1124-1192) 1980. Chos-rgyal mes-dbon rnam-gsumgyi rnam-thar Rin-po-che'i , phreng-ba [The Precious Garland - Hagiography of the three Ancient Pious Kings]. Paro: Ugyen Tempai Gyaltsen.RGM = Sa-skya Bsod-nams Rgyal-mtshan 1981. Rgyal-rabs gsal-ba 'i me-long. [Clear Mirror. A Royal Genealogy] Beijing: Mi-rigs dpe-skrun-khang.

Sba-bzhed = Mgon-po Rgyal-mtshan (ed.) 1982. Sba-bzhed ces-bya-ba-las Sba Gsal-snang-gi bzhed-pa. ["Testament of Sba", an Account of Sba Gsal-snang] Lhasa: Mi-rigs dpe-skrunkhang.

${ }^{50}$ I would like to express my gratitude to Gergely Orosz for generously sharing his precious library with me. 
Sørensen, P. K. 1994. Tibetan Buddhist historiography: The Mirror illuminating the royal genealogies. An annotated translation of the XIVth century chronicle rGyal-rabs gsal-ba'i me-long. Wiesbaden: Harrassowitz Verlag.

Stein, Rolf Alfred (ed.) 1961. Une chronique ancienne de bSam-yas, sBa-bžed (Edition du texte tibétain et résumé français). Paris: Adrien-Maisonneuve.

Taylor, McComas - Yuthok, Lama Choedak (trs.) 1996. The Clear Mirror. A traditional account of Tibet's golden age. Sakyapa Sonam Gyaltsen's Clear Mirror on royal genealogy. (rGyal-rab gsal-ba'i me-long, Bsod-nams rGyal-mtshan Sa-skya-pa bla-ma dam-pa, 1312-1375). Ithaca, New York: Snow Lion.

Tóth, Erzsébet 1996. ,Dzangs-blun zhes-bya-ba'i mdo \| A bölcs és a balga. Klasszikus tibeti olvasókönyv. [Sutra of the Wise and the Foolish. A Classical Tibetan Reader] Budapest: Universitas.

Wangdu, Pasang - Diemberger, Hildegard (eds.) 2000. dBa' bzhed: The Royal Narrative Concerning the Bringing of the Buddha's Doctrine to Tibet. Vienna: Verlag der Österreichischen Akademie der Wissenschaften.

Zahiruddin, Ahmad (tr.) 1995. A History of Tibet by Nag-dBan Blo-bZan rGya-mTSHho, the Fifth Dalai Lama of Tibet. (Indiana University Oriental Series 7.) Bloomington: Indiana University.

\section{Secondary sources}

Afanas'ev, Aleksandr 1945. Russian Fairy Tales. (Tr. Norbert Guterman.) New York: Pantheon Books.

Birtalan Ágnes - Rákos Attila 2002. Kalmükök - Egy európai mongol nép [Kalmyks. A Mongolian People in Europe]. Budapest: Terebess Kiadó.

Cowell, E. B. - Rouse, W. H. D. (tr.) 1907. The Jätaka or Stories of the Buddha's Former Births. Vol. VI. Cambridge: University Press.

Féng, Mǐn (Tr. and notes by Mtsho mo skyid - Gerald Roche) 2010. "Matrilineal Marriage in Tibetan Areas in Western Sìchuān Province." In: Charles Kevin Stuart, Gerald Roche, Tshe dbang rdo rje, Timothy Thurston, and Rin chen rdo rje (eds.) Asian Highlands Perspectives Volume Six. Xining City: Plateau Publications, 251-280.

Frye, Stanley (tr.) 1981. Sutra of the Wise and the Foolish. Dharamsala: Library of Tibetan Works and Archives.

Greßmann, Hugo 1907. "Das salomonische Urteil.” Deutsche Rundschau CXXX: 212-228.

Grimm, Jacob - Grimm, Wilhelm 2013. Grimm's Fairy Tales by The Brothers Grimm. (Tr. Margaret Hunt.) Maplewood Books.

Jones, Alexander (ed.) 1968. The Jerusalem Bible. Reader's Edition. Garden City, New York: Doubleday \& Company.

Kapstein, Matthew T. 2000. The Tibetan assimilation of Buddhism. Conversion, contestation and memory. Oxford University Press.

Martin, Dan 1997. Tibetan Histories: A Bibliography of Tibetan-Language Historical Works. London: Serindia Publications.

Michaud, Alexis 05.08.2015. Online Na-English-Chinese-French Dictionary. (Pangloss Collection. An archive for endangered languages). https://pangloss.cnrs.fr/dictionaries/na/dictionary eng_mp3.pdf and http://himalco.huma-num.fr/dictionaries/SelectDictionary.php?dict=na (accessed 06.06.2020). 
Ruzsa, Ferenc 2007. "The Fertile Clash - The rise of philosophy in India.” In: Csaba Dezső (ed.) Indian Languages and Texts through the Ages. Essays of Hungarian Indologists in Honour of Prof. Csaba Töttössy. Delhi: Manohar, 63-85.

Ruzsa, Ferenc 2015. "Egyfiát áldozza fel" [Sacrificing his only son]. In: Kakas Beáta - Szilágyi Zsolt (eds.) Kéklö hegyek alatt lótuszok tava. Tanulmányok Bethlenfalvy Géza tiszteletére. [A Lotus Lake below Blue Mountains. Studies in Honour of Géza Bethlenfalvy]. Budapest: L'Harmattan, 45-70.

Ruzsa, Ferenc 2016. "Sacrificing his only son. Śunahśepa, Isaac and Snow White." Vallástudományi Szemle 12/5: 94-133.

Ruzsa, Ferenc 2018. “A kannibál bráhminok a mennybe mennek. Rituális tisztaság a MaháBhárata-ban" [Cannibal Brahmins go to heaven. Ritual purity in the Mahābhārata]. In: Kósa Gábor - Vér Ádám (eds.) Purum et immundum. Vallási elképzelések a tisztaságról és tisztátalanságról [Purum et immundum. Religious ideas of purity and impurity]. (HAGION Könyvek 4.) Budapest: ELTE BTK Vallástudományi Központ, 139-164.

Schaik, Sam van 2011. Tibet. A history. New Haven - London: Yale University Press.

Schaik, Sam van - Iwao, Kazushi 2008. "Fragments of the Testimony of Ba from Dunhuang." Journal of the American Oriental Society CXXVIII.3: 477-487.

Schiefner, F. Anton von - Ralston, W. R. S. (tr.) 1906. Tibetan Tales Derived from Indian Sources. Translated From the Tibetan of the Kah-Gyur. London: Kegan Paul, Trench, Trübner \& Co.

Shi, Shuo 08.06.2018. "Ethnic flows in the Tibetan-Yi corridor throughout history." International Journal of Anthropology and Ethnology 2, 2 https://doi.org/10.1186/s41257-018-0009-z (accessed: 10.06.2020).

Szegedi, Mónika 2013a. “A majomremete és a démonnő szerelme. A tibeti nép származásának története" [The love of the monkey hermit and the Demoness. The history of the origin of the Tibetan people]. Vallástudományi Szemle 9.4: 73-91.

Szegedi, Mónika 2013b. “A nőstényördög megszelídül. Tibet megtérése." [The taming of the female devil. The conversion of Tibet]. In: Déri Balázs - Varga Benjámin - Vér Ádám (eds.) Conversio. Az Eötvös Loránd Tudományegyetem Bölcsészettudományi Karán 2011. szeptember 22-23-án tartott vallástudományi konferencia elöadásai. [Conversio. Lectures at the Religious Studies Conference, ELTE BTK 2011. 09. 22-23]. (HAGION Könyvek 1.) Budapest: ELTE BTK Vallástudományi Központ, 261-282.

Tsumagari, Shin'ichi 2013. "Bashey with supplement: A Critical Edition of the Tibetan Text and an Annotated Translation (4)”. 宗教学年報 [Religious studies] XXX: 193-258. 
